\title{
245 肝部下大静脈閉塞症に対する血行再建術
}

関西労災病院 心臟血管外科, 心臟血管研究所附属病院 外科*, 兵庫医科大学 胸部外科**

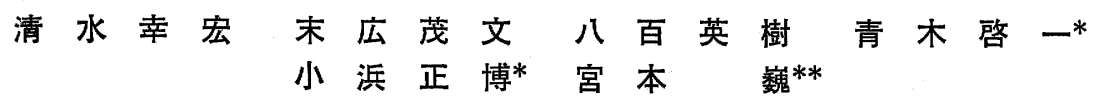

12 年前膜様閉塞を伴う本症の 1 例に対し，ブロッケ ンブロー法を応用したバルーンカテーテルによる膜破砕 術を経験して以来 13 症例に種々の術式を行ってきた. 今回遠隔成績をあとに本症に対する血行再建術式の問題 点につき言及する.

われわれの行った術式は大別すると表 1 のでとくであ り, 膜様閉塞症に対しては, 術式（1）のB法を用いた. 当初はバルーンカテーテルとしてフォガティのカテーテ ルを使用し，最近ではすべて血管拡張用のカテーテルを 使用している. B法にて拡張不十分な場合や症状再発例 には(2)のD法を用いた. 閉塞膜より尾側の下大静脈か ら大腿静脈江至る広範囲の血栓形成を伴った 1 例は胸腹 部正中切開にて人工心肺使用下に血栓除去と, 閉塞膜切 除および $\mathrm{D}$ 法による狭窄部拡張術を行った. 非膜様閉塞 症例の場合には胸腹部正中切開を行い，閉塞部長が短い 症例に( 3 )の 2 万向性, 用指裂開術 BM 法を, 長い場 合に(4)の E-PTFE リング付人工血管による下大静 脈一右心房バイパス術を行った.

症例は 13 例で, 男性 8 例, 女性 5 例で年跉は 16 歳 加ら 58 歳 (平均 44 歳) である. 症例 1 から 9 (9 例) が膜様閉塞で 10 から 13 (4 例) が非膜様閉塞症例で ある, 術後経過観察期間は 1 年半から 12 年 (平均 6 年 2 力月) で, 術前から肝性脳症を伴っていた症例 2 が術 後 9 年目に肝臟障害を伴う全身衰弱にて死亡した以外全

表 1 肝部下大静脈閉塞症に対する手術法

（1） B 法 ブロッケンブロー法による閉塞膜穿刺裂開後, バルーンカテーテルにより閉塞部の裂開拡張を 行う.

$\mathrm{B}(\mathrm{F})$ 法: フォガティーバルーンカテーテル 使用 $\mathrm{B}(\mathrm{D})$ 法：血管拡張用バルーンカテーテル

（2） D法 胸骨正中切開により右心房吕ら僧帽弁口拡張器 を㨉入し，閉塞部の裂開拡張を行う.

（3） BM 法 胸部，腹法正中切開により閉塞部の頭側，尾 側より 2 方向性に角指にて閉塞部裂開搪張を行 う.

（4）G法 胸部, 腹部正中切開により下大静脈と右心房間 江 E-PTFE リング付き人工血管によるバイパ スを行う.
例生存している.

下大静脈造影所見は膜様閉塞例では，症例 2 を除く 8 例に右肝静脈の開存が見られ，8 例中 7 例は閉塞部より 尾側開口していた，症例 8 のが頭側に開口するとと あに，閉塞部直下から大腿静脈に及ぶ広範な血栓形成を 認めた. 非膜様閉塞の 4 例は症例 12 のみに右肝静脈の 開存が見られたが，他の 3 例は主要肝静脈はすべて閉塞 していた. 主要肝静脈閉塞例 4 例中副肝静脈を造影した 2 症例はともに右および中肝静脈之交通する communicating vein の存在を認めた.

図 1 は各手術法における下大静脈, 右心房圧および両 者間の圧較差の術前後の変動を示している．B法におい て術後の圧較差は全例 $10 \mathrm{mmHg}$ 以下に減少したが，5 $\mathrm{mmHg}$ 以下に減少したものは，B(D) 法の 3 例であっ た. $5 \mathrm{mmHg}$ 以上にとどまった 5 症例中 1 例は遠隔期 に $5 \mathrm{mmHg}$ 以下に減少し， 2 症例は症状再発のためと， 合併肝癌手術のためおのおの D法を行った. 他の 3 術式 では圧較差は全例 $5 \mathrm{mmHg}$ 以下に減少した.

次に遠隔成績を検討した. 図 2 は膜様閉塞 9 例の下大 静脈一右心房間圧較差の変動と遠隔予後を見たものであ る. 初回手術により圧較差 $5 \mathrm{mmHg}$ 以下に減少したむ のは B(D) 法の 2 例と D法の 2 例であり $\mathrm{B}(\mathrm{F})$ 法の 1 例は術後 2 年の圧測定にて $5 \mathrm{mmHg}$ 以下に減少してい た. 乙の 5 症例は初回手術後 1 年半から 9 年（平均 4 年 10 力月）の現在無症状である，5 10 mmHg の圧較差 の残存を認めた 4 症例中 2 例は術後 9 年の現在と屯に症 状再発すなく経過良好である. 症例 1 は $B(F)$ 法施行 後 4 年目の症状再発に対しD法を行い，その後 8 年間無 症状であり 4 年後の圧測定であ圧較差の増大は見られな 加た. 肝性脳症を伴った症例 2 は初回の $\mathrm{B}(\mathrm{F})$ 法で は効果不十分であり，その後再手術を拒否していた，術 後 7 年目に B(D) 法を行って圧較差は $3 \mathrm{mmHg}$ まで 下降したが肝不全を伴う全身衰弱にて，その半年後に死 亡した.

次に非膜様閉塞の遠隔成績では，BM 法の 1 例は狭 窄の再発に対して術後 2 力月, 7 力月, 1 年 8 力月の計 

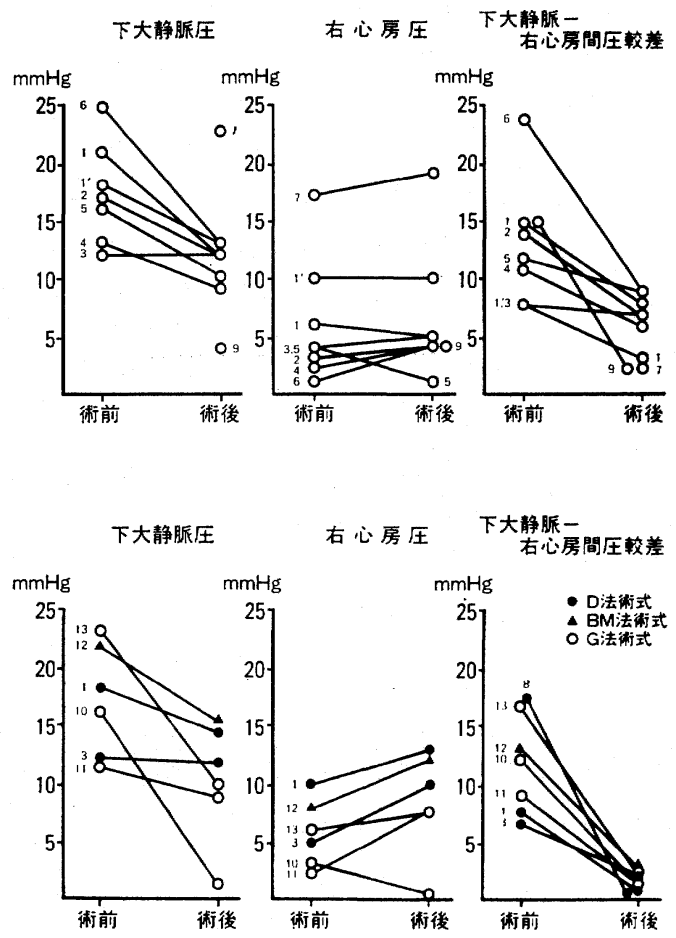

図 1 肝部下大静脈膜様閉塞の穿刺裂開（B法）前後の圧変動（数字は症例ナンバー）(上) と transcardiac membranotomy (D法), bidirectional digital-instrumental membranotomy (BM 法)，IVC-RA バイパス術（G法）前後の圧変動（数字は症例ナンバ - (下)

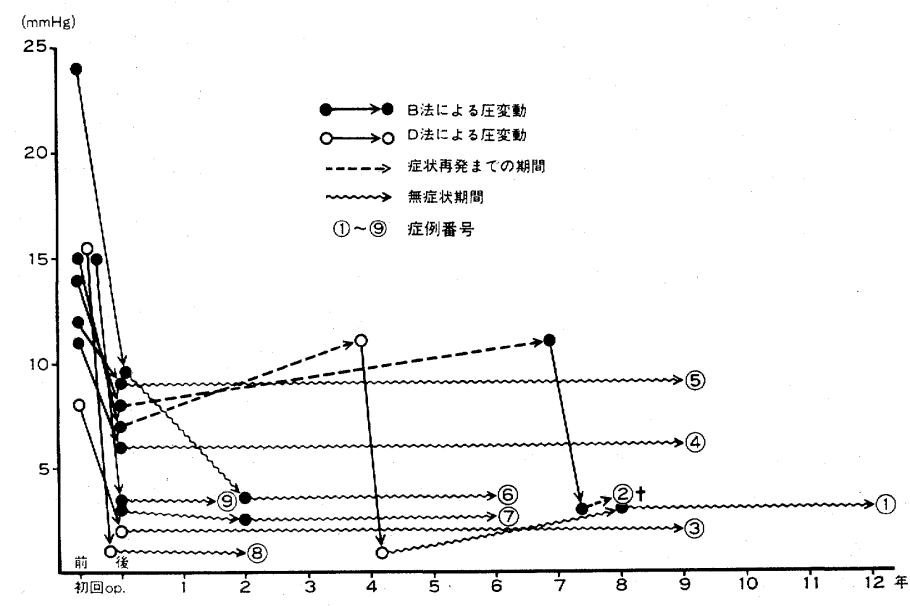

図 2 VCI-RA 圧較差の変動および遠隔予後（膜様閉塞症例）

3 回 B(D) 法による拡張術を必要とした. G法の 3 例 中 1 例は術後 5 年の造影です, グラフトの開存性は良好 で術後早期の造影像とまったく変わらず，圧較差む 2 $\mathrm{mmHg}$ と不変であった. 他の 2 例では術後早期の造影
所見は良好であったが，両者ともに遠隔期の造影にてグ ラフトと下大静脈の吻合部に狭窄を生じ，D法による拡 張術を必要とした，症例 10 は同吻合部位の肝臟側に閉 塞を生じたため，同側の下大静脈と開存するグラフトの 
間に新たなバイパスを設置した，両例ともにベーチェッ 卜氏病，およびシーグレン症候群十橋本病という自己免 疫突患を合併する症例であり, 下大静脈周团組織の浮腫 が著明で，壁屯白色線維化之肥厚を伴っていた．このよ うな症例には吻合部の狭窄化を防止するための工夫が必 要と考えられ, 状態が許せば, 直視下根治手術の適応之 思われた。

\section{結論}

1）肝部下大静脈膜様閉塞症に対し，ブロックケンブ ロー法を応用したバルーンカテーテルによる穿刺裂開 術，ならびに右心房汃ら挿入した僧帽弁口拡張器による 裂開拡張術は侵襲む少なく遠隔成績む良好であり本症に
対する第一および第二選択となる術式と考え引れた。

2）非膜様閉塞症に対する 2 方向性用指裂開術は 1 例 の経験であるが, 術後再三の狭窄に対しバルーンカテー テルによる拡張術を必要とした. E-PTFE リング付グ ラフトによる下大静脈-右心房間のバイパス術 3 例では, 自己免疫疾患を伴う 2 例に遠隔時の末梢側吻合部位に狭 窄をみとめたが，他の 1 例は 5 年後の開存性も良好であ った．したがって，末梢側の吻合部狭窄を防止する術式 上の工夫が必要と考えられる.

3）閉塞部末梢側に広範囲の血栓形成を有する膜様閉 塞例に対し胸腹部正中切開にて人工心肺使用下に肝脱転 を行うことなく血栓除去ならびに閉塞膜切除十狭窄部搪 張術を行い良好な結果を得た。

\section{6 覀性腫瘍の大静脈浸潤，静脈内腫瘍血栓症に対する 血行再建の検討および遠隔成績}

\section{札幌医科大学 第 2 外科 \\ 井上紀雄松崎智哉伊藤敏行山田修

数 井暉 久小松 作 蔵

縦隔腫瘍や後腹膜に発生する腫瘍は大血管とくに大静 脈と近接した位置関係にあり，大静脈への浸潤，閉塞ま たは静脈内腫瘍血栓をひきおこすととがまれでなく， 外科潦治の 際大静脈の合併切除 および再建が必要とな $ろ^{1,2}$. 今回悪性腫瘍による大静脈浸潤，閉塞および静 脈内腫瘍血栓の 11 例に腫演切除, 静脈再建を施行し, 外科治療上の問題点, 遠隔成績について検討したので報 告する.

\section{対象}

対象は 1980 年より 1987 年 10 月までに悪性腫瘍の 大静脈浸潤，閉塞および静脈内腫瘍血栓症をきたした 11 例で, 年齢は 4 77 歳, 平均 56 歳で, 男 8 例, 女 3 例であった，悪性腫湯による分類では腎細胞癌 (Grawitz）による下大静脈腫瘍血栓症 8 例, Wilms 腫瘍に 上る下大静脈腫癔血栓症 1 例であった． 9 例の左右別は 左 3 例, 右 6 例であり, 静脈内腫湯血栓の進展レベルは 腎静脈開口部 8 例，肝静脈開口部 1 例であった．腫瘍の stage 分類はIII度 5 例, IV 度 4 例であり, IV 度の 4 例で は肺転移 3 例，脳転移 1 例が術前の検索でみとめられた
（表 1 ）。他の 2 例は浸潤型胸腺腫による右腕頭静脈完全 閉塞 1 例，左腕頭静脈および上大静脈浸潤 1 例であった (表 2).

腎癌による下大静脈腫瘍血栓症では経胸腹的アプロー チで 8 例, 経腹的アプローチで 1 例手術を施行した．経 胸腹的アプローチでは第 10 または 11 肋骨を切除し, 切除部位にて開胸し, 次いで横隔膜を切開し腹腔内に達 し，後腹膜を切開した，左右の腎静脈を剝離し，次いで 患側腎動脈をその起始部にて結禁し腎への血流を遮断し た. 下大静脈を腫瘍血栓の上下 $10 \mathrm{~cm}$ にわたり剝離, 遮断し，対側腎静脈屯遮断した，患側腎静脈開口部を繸 切開し，患側腎静脈ごと腫瘍血栓を摘出した。また同時 亿患側腎も周囲の脂肪組織と一塊に切除した，下大静脈 は連続 2 重直接縫合した，浸潤型胸腺腫の 2 例では胸骨 正中切開にて縦隔に到達し, 左腕頭静脈-上大静脈, 左 腕頭静脈一右心耳バイパスを施行し，次に腫瘍を浸潤さ れた静脈ととあに一塊として摘出した。 バイパスに用い た人工血管は EPTFE グラフトで内径は $16 \mathrm{~mm}$ と 12 $\mathrm{mm}$ であった。 